\title{
MATHEMATICAL CRITICAL THINKING SKILL OF MADRASAH IBTIDAIYAH STUDENTS ON CUBES AND BEAM VOLUMES MATERIAL
}

\author{
Anas Salahudin', Inne Marthyane Pratiwi ${ }^{2}$, Syaeful Hidayat ${ }^{3}$ \\ Universitas Islam Negeri Sunan Gunung Djati Bandung, Indonesia ${ }^{1,2,3}$ \\ E-mail: anassalahudin@uinsgd.ac.id ${ }^{1}$,inne.mp@uinsgd.ac.id², \\ saefulhidayat090998@gmail.com ${ }^{3}$
}

DOI: $\underline{10.14421 / \text { al-bidayah.v12i1.349 }}$

\begin{abstract}
This research-based on the findings that elementary school students already have mathematical critical thinking skills but have not reached the whole stage of the skills. Critical thinking skills of mathematics is essential for students because critical mathematical thinking can solve the problems and as a consideration to make decisions. This research aims to: (1) explore the critical thinking skills of mathematics of the subject of the volume of cubes and beams; (2) to determine student's difficulties in solving mathematical critical thinking skills test questions on the subject of the volume of cubes and beams. The research used a case study method of 28 students in one of the Islamic elementary schools in Bandung Regency. The data collected in the form of qualitative data obtained through tests of mathematical critical thinking skills, interviews, and document analysis. Data analysis techniques used thematic analysis by analyzing students' learning trajectory. The results showed that most students were still in the low category in the ability of critical thinking. As for the difficulties experienced by students, namely in providing simple explanations and working on problems that are not systematic. For this reason, the improving of students' mathematical critical thinking skills need further research.
\end{abstract}

\section{Keywords: learning obstacle; learning trajectory; critical mathematical thinking; the volume of cubes; volume of beams}

\section{INTRODUCTION}

The Government, through the Ministry of Education and Culture (MoEC) of Indonesia, has made several efforts to achieve national education goals. One of the efforts made is the integration of Higher Order Thinking Skills (HOTS) in learning. ${ }^{1}$ Teachers in elementary schools and madrasah ibtidaiyah must be able to direct students to think critically, analytically, and be able to conclude or problem-solving to prepare students to be ready to compete in the face of the Industrial Revolution Era 4.0.

HOTS includes critical, logical, reflective, metacognitive, and creative thinking skills. Critical thinking is one of the learning skills developed in education in the 21 stcentury reform era. ${ }^{2}$ According to Ennis, critical thinking is a process that is accompanied

1 Ridwan Abdulllah Sani, Pembelajaran Berbasis HOTS (Higher Order Thinking Skills) (Tangerang: Tira Smart, 2019), 1.

${ }^{2}$ Yunus Abidin, Pembelajaran Multiliterasi (Sebuah Jawaban Atas Tantangan Pendidikan Abad 21) (Bandung: Refika Aditama, 2015); Diah Eka Pratiwi and Mawardi Mawardi, "Penerapan Model Pembelajaran Inquiry dan Discovery Learning Ditinjau dari Keterampilan Berpikir Kritis Pada Mata Pelajaran Matematika Di Sekolah Dasar," Jurnal Basicedu 4, no. 2 (March 4, 2020): 288-94, https://doi.org/10.31004/basicedu.v4i2.345. 
by accurate and reflective reasons to decide on something. ${ }^{3}$ The importance of critical thinking is to be able to make decisions and be responsible for what they will be believed and done. Furthermore, the students need reliable information and understanding of the topic or field study to decide what students believe and do. ${ }^{4}$

Critical thinking is related to drawing meaning skill from the statement or data provided. A person who can think critically must be able to make reason and interpretations. Someone who has thinking skills will be able to implement their knowledge to manipulate information to find solutions to a new problem. ${ }^{5}$ Mathematics is one of the subjects that can develop critical thinking skills. ${ }^{6}$

Mathematics is a universal science that underlies the development of modern technology today. Afifah said if mathematics can develop the potential of reasoning skills. ${ }^{7}$ On the other hand, mathematic thinking has a structure and a strong connection between concepts so the students will have rational thinking, critical thinking, systematic, logical, and creative skills. ${ }^{8}$

By learning of mathematics, students can think logically, analytically, systematically, critically, and creatively, and can work together. Critical thinking in learning mathematics is an activity to obtain mathematical knowledge through mathematical critical thinking skills ${ }^{9}$. Having critical thinking in learning mathematics is

3 Retni Paradesa, "Kemampuan Berpikir Kritis Matematis Mahasiswa Melalui Pendekatan Konstruktivisme Pada Matakuliah Matematika Keuangan," Jurnal Pendidikan Matematika RAFA 1, no. 2 (2015): 306-25., http://jurnal.radenfatah.ac.id/index.php/jpmrafa/article/view/1236.

4 In Hi Abdullah, "Berpikir Kritis Matematik," Delta-Pi: Jurnal Matematika dan Pendidikan Matematika 2, no. 1 (September 23, 2016), https://doi.org/10.33387/dpi.v2i1.100.

${ }^{5}$ Sani, Pembelajaran Berbasis HOTS (Higher Order Thinking Skills), 1-2.

6 Indri Herdiman et al., "Kemampuan Berpikir Kritis Matematik Siswa SMP Pada Materi Lingkaran," PRISMA 7, no. 1 (June 30, 2018): 1-10, https://doi.org/10.35194/jp.v7i1.213; Chandra Novtiar and Usman Aripin, "Meningkatkan Kemampuan Berpikir Kritis Matematis Dan Kepercayaan Diri Siswa SMP Melalui Pendekatan Open Ended," PRISMA 6, no. 2 (December 30, 2017): 119-31, https://doi.org/10.35194/jp.v6i2.122.

${ }^{7}$ Billy Suandito, "Bukti Informal Dalam Pembelajaran Matematika," Al-Jabar : Jurnal Pendidikan Matematika 8, no. 1 (June 19, 2017): 13-24, https://doi.org/10.24042/ajpm.v8i1.1160.

${ }^{8}$ Rahmi Fuadi, Rahmah Johar, and Said Munzir, "Peningkatkan Kemampuan Pemahaman Dan Penalaran Matematis Melalui Pendekatan Kontekstual," Jurnal Didaktik Matematika 3, no. 1 (April 19, 2016): 47-54; http://www.jurnal.unsyiah.ac.id/DM/article/view/4305. Zetriuslita Zetriuslita, Rezi Ariawan, and Hayatun Nufus, "Analisis Kemampuan Berpikir Kritis Matematis Mahasiswa Dalam Menyelesaikan Soal Uraian Kalkulus Integral Berdasarkan Level Kemampuan Mahasiswa," Infinity Journal 5, no. 1 (February 1, 2016): 56-66, https://doi.org/10.22460/infinity.v5i1.p56-66.

9 Retni Paradesa. "Kemampuan Berpikir Kritis Matematis Mahasiswa Melalui Pendekatan Konstruktivisme pada Matakuliah Matematika Keuangan”, Jurnal Pendidikan Matematika RAFA 1, no. 2 (2016): 306-325, http://jurnal.radenfatah.ac.id/index.php/jpmrafa/article/view/1236. 
critical because critical thinking has usefulness, such as solving problems and make decisions both in mathematics and in other subjects.

The results of research conducted by Trends in Mathematics and Science Study (TIMSS) in 2015, Indonesia ranked 20th out of 44 international levels in the reasoning category. ${ }^{10}$ This result means that the reasoning abilities of Indonesian students have not yet reached optimal results. Facts in the field show that students' critical thinking skills are still low because they have not been trained in testing, questioning, connecting, and evaluating in a situation. ${ }^{11}$ Other research found that elementary students have essential mathematical critical skills, but they have not reached all the stages of critical thinking. ${ }^{12}$

Based on the explanation before, the researchers tried to research the analysis of the mathematical critical thinking skills of madrasah ibtidaiyah students. The subject matter raised is the volume of the cube and beam. The researcher conducted this research intending to explore mathematical critical thinking skills and to find out students' difficulties in finishing mathematical critical thinking skill test.

\section{RESEARCH METHODS}

This research used qualitative research. Qualitative research is research aimed at describing and analyzing phenomena, perceptions, or thoughts of individuals individually or in groups. ${ }^{13}$ The research used a case study because the purpose of this research is to explore mathematical critical thinking skills. The research field was in one of the Madrasah Ibtidaiyah in Bandung Regency. The research participants were 28 fifth grade students. In this study, the researchers gave tests of mathematical critical thinking skills and document analysis. The implementation of the test applied a breakdown of questions arranged based on indicators of mathematical critical thinking skill of the cube and the beam's volumes material. The documents analyzed were the results of student tests.

\footnotetext{
${ }^{10}$ Ina V.S. Mullis et al., TIMSS 2015 International Results in Mathematics (Boston: International Association for the Evaluation of Educational Achievement, 2016).

${ }^{11}$ Lydia Lia Prayitno, Ida Sulistyawatii, and Imas Srinana Wardani, "Profil Kemampuan Berpikir Kritis Siswa SD Di Kecamatan Bulak," Jurnal Pendidikan Dasar Nusantara 1, no. 2 (January 13, 2016), https://ojs.unpkediri.ac.id/index.php/pgsd/article/view/216.

${ }^{12}$ Mira Azizah, Joko Sulianto, and Nyai Cintang, "Analisis Keterampilan Berpikir Kritis Siswa Sekolah Dasar Pada Pembelajaran Matematika Kurikulum 2013," Jurnal Penelitian Pendidikan 35, no. 1 (July 20, 2018): 61-70-70, https://doi.org/10.15294/jpp.v35i1.13529. 2015), 60 .

13 Nana Syaodih Sukmadinata, Metode Penelitian Pendidikan (Bandung: Remaja Rosdakarya,
} 
Through the documents, researchers can conduct student trajectory learning analysis and learning obstacles.

Data analysis in this study used a qualitative approach with thematic analysis. Thematic analysis is a data analysis technique that is done by looking at and finding themes and categories obtained in the data that was the output from the coding process its before. ${ }^{14}$ The stages of data analysis in this research are (1) preparing raw data; (2) reading the entire data; (3) data coding; (4) linking the results of coding; (5) interpret the results of coding. 15

\section{RESULT AND DISCUSSION}

The researcher prepared six questions of mathematic critical thinking skill test to the students in the form of description. Meanwhile, only three items that represent the indicators of mathematical critical thinking skills would be analyzed. The following are the results of the students' tests.

\section{Question Number 2}

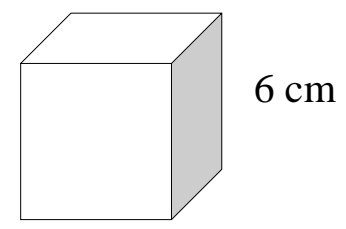

What is the volume of the cube above?

Question number 2 is about the calculation of geometry volume, a cube; with one of the edge length is $6 \mathrm{~cm}$. The following results of the tests are:

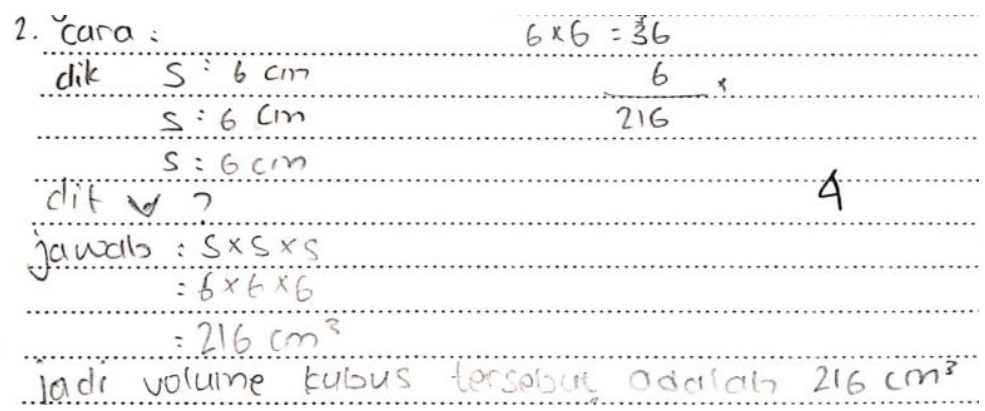

Figure 1

The Answer Type A Question Number 2

${ }^{14}$ Glenda Mac Naughton, and Patrick Hughes, Doing Action Research in Early Childhood Studies: A Step by Step Guide (USA: Open University Press, 2009).

15 John W. Creswell, Research Design: Qualitative, Quantitative, and Mix Methods Approaches, 3rd ed. (California: SAGE Publication, Inc., 2009). 
Figure 1 is one of the right answers. The students answered by following the indicators of critical thinking. First, the students mention a simple explanation of the problem by writing "identified (diketahui)" in which it explained one of the edge lengths of the cube is $6 \mathrm{~cm}$ and "questioned (ditanya)" in which it asked that the students must find the volume of the geometry. Then, the students wrote the essential skills that were

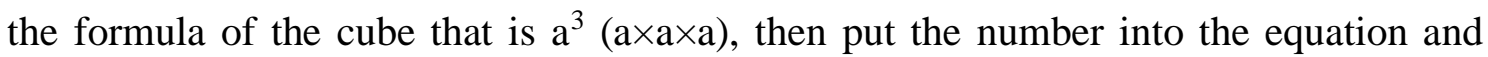
calculate them; $6 \mathrm{~cm} \times 6 \mathrm{~cm} \times 6 \mathrm{~cm}=216 \mathrm{~cm}^{3}$. Furthermore, the students write a conclusion at the end of their answer. Two students answered question number 2 correctly. However, 14 students responded that the necessary skills stage correctly, but did not follow the procedure in critical thinking and did not mention the units.

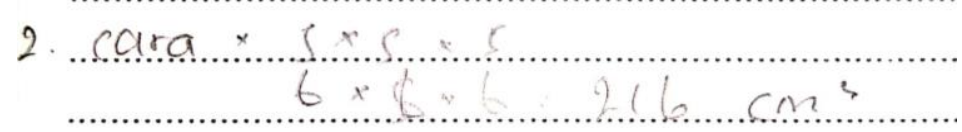

Figure 2

The Answer Type B Question Number 2

Figure 2 is one of the correct answers, but the students only replied in the basic skills indicator that only mentioned in the formula and one of the edges of the cube. The students responded a $\mathrm{x}$ a $\mathrm{x} \mathrm{a}=6 \times 6 \times 6=216 \mathrm{~cm}^{3}$. Two students responded, like Figure 2. Formerly, there was a unique thing when the students replied to the question. They multiplied the numbers, not all in once but bit by bit. For example: $6 \times 6 \times 6=36 \times 6=$ $216 \mathrm{~cm}^{3}$. Two students responded distinctively like that. Furthermore, two students replied directly, namely 216, but did not use a systematic way and did not follow the existing indicators in critical thinking skills.

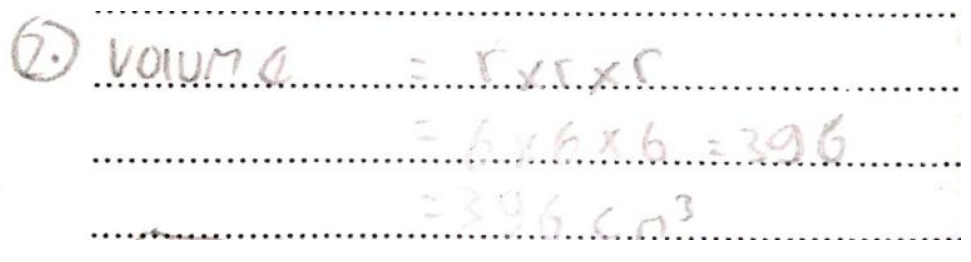

Figure 3

The Answer Type C Question Number 2

Figure 3 shows the students who answered the question were not carefully, proving that the students wrote " $\mathrm{r}$ " as the edge length of the cube symbol instead of the letter "a". Thus, the students insert numbers from either side into the formula. That was $r$ 
$\times \mathrm{r} \times \mathrm{r}=6 \times 6 \times 6=396 \mathrm{~cm}^{3}$, but the answer was incorrect. The correct answer should be $216 \mathrm{~cm}^{3}$. Three students replied, as shown in Figure 3.

\section{Question Number 4}

Mr. Ahmad will make a total of 12 cuboids, with a length of $30 \mathrm{~cm}$, breadth $20 \mathrm{~cm}$, and height $15 \mathrm{~cm}$. How long is the wire that Pak Ahmad needs to make 12 cuboids?

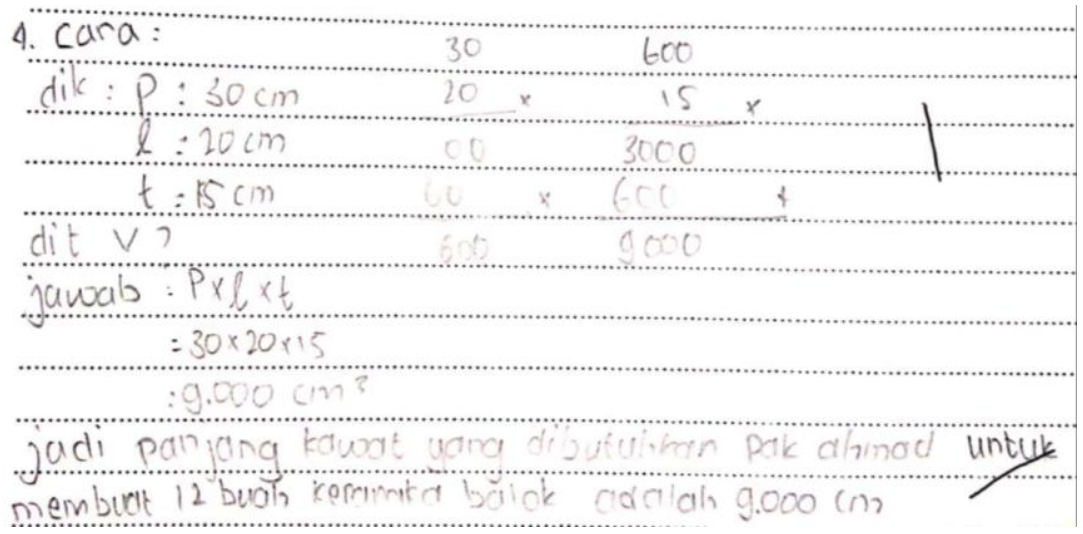

Figure 4

The Answer Type A Question Number 4

Figure 4 shows that the students mentioned the indicators that were in critical thinking skills. However, when writing a simple explanation, the students wrote incompletely, which was lacking in including the frame of the cuboids made that should be 12 pieces. Then in a simple statement, it was known that the students should answer the length of wire needed to make 12 cuboids. Furthermore, in writing simple skills, the students only multiply $1 \times b \times h$. Four students were answering, as shown. Then nine students answered with no arithmetic units.

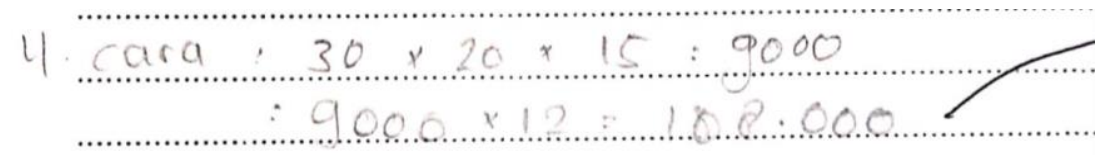

Figure 5

The Answer Type B Question Number 4

Figure 5 shows an incorrect answer. Because the students only calculate $1 \times b \times h$ $=30 \times 20 \times 15=9,000$, then multiply it by 12 pieces of cuboids so that it became 108,000. The students should follow the indicators of critical thinking. Six students answered, like in Figure 5. Then there was one student who answered at once, $12 \times 30 \times 20 \times 15=$ 108.000. But the answers were all incorrect. 


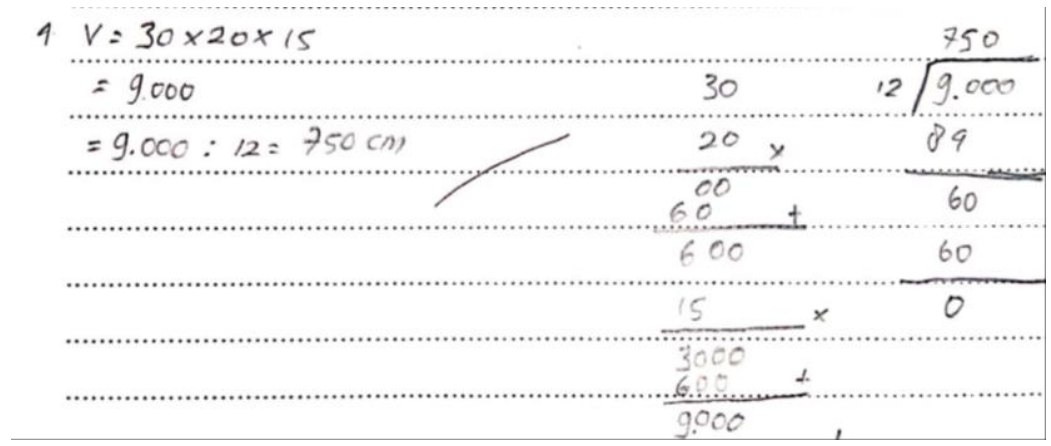

Figure 6

The Answer Type C Question Number 4

Figure 6 shows that the students have done their test improperly. The students only answered $\mathrm{V}=30 \times 20 \times 15=9,000$ then divided by 12 so it became $750 \mathrm{~cm}$. However, the students were still wrong in the placement of arithmetic operations in a story test form. Two students answered, as shown.

\section{Question Number 6}

Mr. Yuda has a large aquarium in the form of a beam with a length of $120 \mathrm{~cm}$, breadth 75 $\mathrm{cm}$, and height $100 \mathrm{~cm}$. If the aquarium is half-filled with water, then how many liters of water are needed?

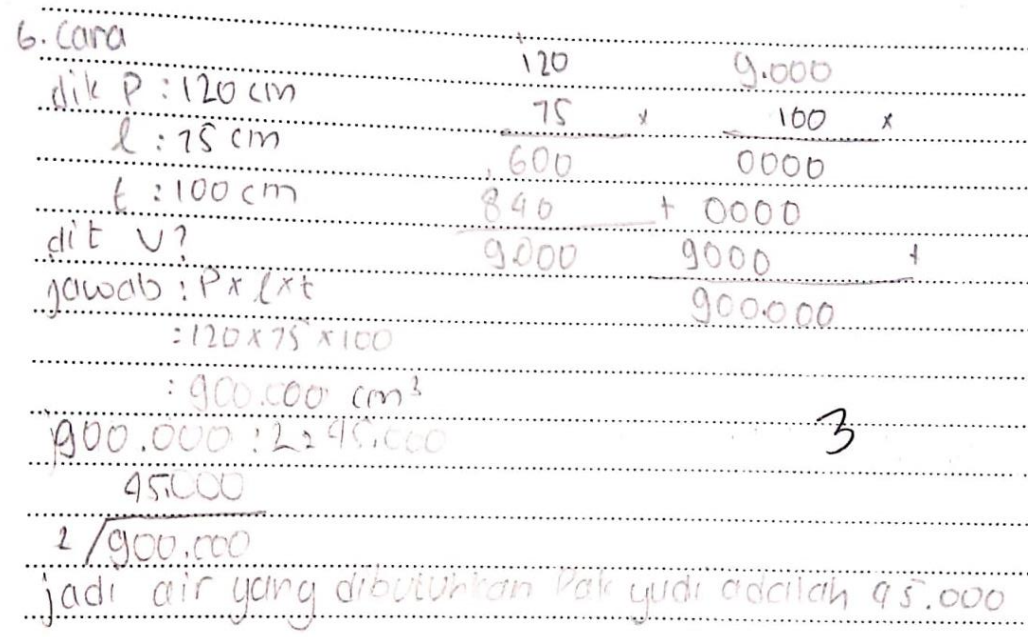

Figure 7

The Answer Type A Question Number 6

Figure 7 shows that the product the students' worksheets have followed the indicators. First, the students explained simply by writing down identified (diketahui) and asked (ditanya) ultimately. The two students wrote down necessary skills by writing the formula of the cuboid and set the numbers that were already known; after that, it was divided in half because it was only filled with half the water. But when the volume was 
divided by 2 , the students were not careful in dividing it so that the final result of the work was incorrect; it should be $900,000 \div 2$ is 450,000 . However, the students answered 45,000, which were less accurate in giving the number 0 (zero). Six students responded, as shown in Figure 7 above.

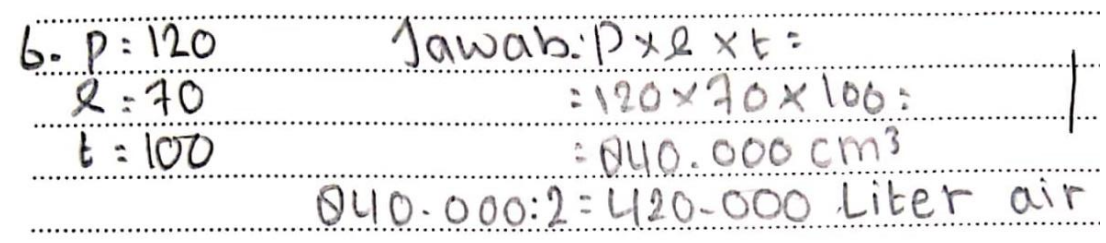

Figure 8

The Answer Type B Question Number 6

Figure 8 is the answer to the students' worksheets, which were less precise and less systematic. First, the students did not mention what the teacher asked them. Then when writing down the essential skills, the students were not careful in multiplying it, which should answer $900,000 \mathrm{~cm}^{3}$, but the students answered 840,000. After that, the students divided the two volumes, but the students should change from $900,000 \mathrm{~cm}^{3}$ into liter units, and then divided by two, the answers should be 450 liters. There was one student who answered like that. Then two students answered after being multiplied into a volume instead divided into three contents $300,000 \mathrm{~cm}^{3}$.

The research showed the descriptions of the students' mathematical critical thinking skill that were analyzed based on the students' learning trajectory in solving mathematical critical thinking skill test questions on cubes and beam volume's subject matter consisted of: (1) information collection and setting structurally, (2) careful thinking, (3) systematically thinking, and (4) logical conclusion. Based on the findings, the researchers indicated that the completion of several students' questions was different but produced the same conclusions. In solving the problem, the way was categorized as a contrast. Such as Pratiwi, Rahman, and Ariawan stated that contrast was an alternative to solving mathematics problems in a slightly different way from the example. ${ }^{16}$ Each question analyzed contains three indicators of critical thinking skill, namely (1) provide

${ }^{16}$ I. M. Pratiwi, S. P. D. Rachman, and V. A. N. Ariawan, "Students' Mathematical Understanding Reviewed by Gender through Discourse Learning Assisted by Mathematical Bet Line Strategy," Journal of Physics: Conference Series 1157 (February 2019): 042103, https://doi.org/10.1088/1742$6596 / 1157 / 4 / 042103$. 
a simple explanation; (2) build necessary skills, and (3) conclude. ${ }^{17}$ The first indicator, the students often did not provide simple explanation information on the problem by including things that were "identified (diketahui)" and "asked (ditanya)." The students inclined to pass the first indicator and went directly to the second indicator. Furthermore, in the third indicator in providing conclusions, some students were correct, but some students were still not perfect in providing findings that did not include the arithmetic units.

In the 21 st century learning, the improvement of student's reasoning abilities is important and primary. One of them is by increasing the ability to think critically. Critical thinking skill, according to Krulik and Rudnick, is the part of the reasoning. ${ }^{18}$ According to Dewey, critical thinking is an active and thorough process. ${ }^{19}$ It means in essential skills of thinking; the students must understand and evaluate the information. When the data is passed in or come to the students, they must be able to think in advance to conclude.

The students need to develop their ability of critical thinking because through this; the students can more easily understand the concepts, be sensitive to the problems that occur so they can understand and solve the issues, and can apply the concepts in different situations. The development of critical thinking skills in the learning process requires the expertise of the teacher. ${ }^{20}$ Knowledge in choosing the right media is one of the factors that determine the success of developing students' critical thinking skills.

The development of optimal critical thinking skills requires interactive classes. For learning to be interactive, the learning design must be impressive so students can be actively involved in the learning process. ${ }^{21}$ In learning that develops critical thinking skills, it engages more students, thinkers, not someone who is only to be taught. The instructor acts as a facilitator and motivator who help the students in learning and not only teaching.

\footnotetext{
${ }^{17}$ Ahmad Susanto, Teori Belajar Dan Pembelajaran Di Sekolah Dasar (Jakarta: Kencana Prenada Media Group, 2013).

${ }^{18}$ Rini Utami, "Model Pembelajaran Berbasis Masalah Dengan Langkah Penyelesaian Berdasarkan Polya Dan Krulik-Rudnick Ditinjau Dari Kreativitas Siswa," Delta: Jurnal Ilmiah Pendidikan Matematika 1, no. 1 (August 14, 2017): 82-98, https://doi.org/10.31941/delta.v1i1.464.

${ }^{19}$ Abidin, Pembelajaran Multiliterasi (Sebuah Jawaban Atas Tantangan Pendidikan Abad 21).

${ }^{20}$ Dara Puspita Dewi et al., "Analisis Kemampuan Berpikir Kritis Matematis Siswa Smp Pada Materi Lingkaran Dan Bangun Ruang Sisi Datar," JPMI (Jurnal Pembelajaran Matematika Inovatif) 2, no. 6 (September 4, 2019): 371-78, https://doi.org/10.22460/jpmi.v2i6.p371-378.

${ }^{21}$ Dwi Wulan Suci, Firman Firman, and Neviyarni Neviyarni, "Peningkatan Keterampilan Berpikir Kritis Siswa Melalui Pendekatan Realistik Di Sekolah Dasar," Jurnal Basicedu 3, no. 4 (November 16, 2019): 2042-49, https://doi.org/10.31004/basicedu.v3i4.229.
} 
The subsequent analysis is about the students' difficulties in completing questions about students' thinking skills. The types of mistakes made by students include (1) wrong in interpreting the purpose of the problem, (2) wrong when performing a count operation, and (3) wrong in concluding.

The students cause errors in interpreting the purpose of the problem to have low reading comprehension in mathematical sentences. Even though the students' difficulties in solving mathematical problems can be overcome with a new perspective, namely through discourse related to linguistics, ${ }^{22}$ by avoiding this type of student mistakes, it will indirectly improve the critical thinking skill of the second indicator.

The cause of errors in calculating operations is the lack of students' understanding of the prerequisite material and students' difficulties in developing problem-solving strategies. The prerequisite material needed to understand cubes and beams volumes is about the properties of cubes and beams, flat structures, and multiplication and division operations. The subject matter, which is a prerequisite material, has been studied at the previous grade level. One of the problem-solving strategies that can be built through problem-solving steps, Polya stated, namely understanding the problem, planning the problem solving, implementing the problem solving plan, and checking again. ${ }^{23}$ Meanwhile, carefulness is needed to solve test questions for critical mathematical thinking. By avoiding the second type of error, the students can develop the second indicator, which is building essential skills can be improved.

The process of concluding becomes important in mathematical critical thinking skills. The reason is that students' critical thinking skills must understand and evaluate information, and while the information is entering students, they must be able to think in advance to conclude. This type of difficulty can be avoided when students work systematically. By reducing this type of error, it can improve the mathematical critical thinking skill of the third indicator, which is to conclude.

22 Sumarwati -, "Soal Cerita Dengan Bahasa Komunikatif Untuk Meningkatkan Kualitas Pembelajaran Matematika Sekolah Dasar," Jurnal Ilmu Pendidikan 19, no. 1 (2013), https://doi.org/10.17977/jip.v19i1.3752.

${ }^{23}$ G. Polya, How to Solve It: A New Aspects of Mathematical Method (Garden City, New York: Doubleday \& Company Inc., 1957), https://math.hawaii.edu/home/pdf/putnam/PolyaHowToSolveIt.pdf. 


\section{CONCLUSION}

Based on the analysis of the learning trajectory, students solve problems with different alternative solutions. The students often solve problems without passing through the first indicator stages, namely simple explanation. Students have been good at building basic skill indicators. In drawing conclusions stage, students rarely include the unit of calculation. Furthermore, there are three mistakes made by students.

Errors in interpreting questions can affect giving a simple explanation indicator (primary clarification). Errors in arithmetic operations can affect build primary skill indicator (essential support). Meanwhile, the obstacles in concluding can affect concluding. Students need to develop critical thinking skills because they can more easily understand concepts, be sensitive to problems that occur so they will be implementing the concepts in different situations. In the learning process, the development of critical thinking skills requires the expertise of the teacher. Based on this reason, further research is needed to improve mathematical critical thinking skills by implementing an appropriate learning model or media.

\section{REFERENCES}

Abdullah, In Hi. "Berpikir Kritis Matematik." Delta-Pi: Jurnal Matematika dan Pendidikan Matematika 2, no. 1 (September 23, 2016). https://doi.org/10.33387/dpi.v2i1.100.

Abidin, Yunus. Pembelajaran Multiliterasi (Sebuah Jawaban Atas Tantangan Pendidikan Abad 21). Bandung: Refika Aditama, 2015.

Azizah, Mira, Joko Sulianto, and Nyai Cintang. "Analisis Keterampilan Berpikir Kritis Siswa Sekolah Dasar Pada Pembelajaran Matematika Kurikulum 2013.” Jurnal Penelitian Pendidikan 35, no. 1 (July 20, 2018): 61-70-70. https://doi.org/10.15294/jpp.v35i1.13529.

Creswell, John W. Research Design: Qualitative, Quantitative, and Mix Methods Approaches. 3rd ed. California: SAGE Publication, Inc., 2009.

Dewi, Dara Puspita, Dinar Mediyani, Wahyu Hidayat, Euis Eti Rohaeti, and Tommy Tanu Wijaya. "Analisis Kemampuan Berpikir Kritis Matematis Siswa Smp Pada Materi Lingkaran Dan Bangun Ruang Sisi Datar." JPMI (Jurnal Pembelajaran Matematika Inovatif) 2, no. 6 (September 4, 2019): 371-78. https://doi.org/10.22460/jpmi.v2i6.p371-378.

Fuadi, Rahmi, Rahmah Johar, and Said Munzir. "Peningkatkan Kemampuan Pemahaman Dan Penalaran Matematis Melalui Pendekatan Kontekstual.” Jurnal Didaktik Matematika 3, no. 1 (April 19, 2016): 47-54, http://www.jurnal.unsyiah.ac.id/DM/article/view/4305. 
Herdiman, Indri, Ilfa Febrina Nurismadanti, Pusparini Rengganis, and Neni Maryani. "Kemampuan Berpikir Kritis Matematik Siswa SMP Pada Materi Lingkaran." PRISMA 7, no. 1 (June 30, 2018): 1-10. https://doi.org/10.35194/jp.v7i1.213.

Mullis, Ina V.S., Michael O. Martin, Pierre Foy, and Martin Hooper. TIMSS 2015 International Results in Mathematics. Boston: International Association for the Evaluation of Educational Achievement, 2016.

Naughton, Glenda Mac, and Patrick Hughes. Doing Action Research in Early Childhood Studies: A Step by Step Guide. USA: Open University Press, 2009.

Novtiar, Chandra, and Usman Aripin. "Meningkatkan Kemampuan Berpikir Kritis Matematis Dan Kepercayaan Diri Siswa SMP Melalui Pendekatan Open Ended." PRISMA 6, no. 2 (December 30, 2017): 119-31. https://doi.org/10.35194/jp.v6i2.122.

Paradesa, Retni. "Kemampuan Berpikir Kritis Matematis Mahasiswa Melalui Pendekatan Konstruktivisme Pada Matakuliah Matematika Keuangan." Jurnal Pendidikan Matematika RAFA 1, no. 2 (2015): 306-25, http://jurnal.radenfatah.ac.id/index.php/jpmrafa/article/view/1236.

Polya, G. How to Solve It: A New Aspects of Mathematical Method. Garden City, New York: Doubleday \& Company Inc., 1957. https://math.hawaii.edu/home/pdf/putnam/PolyaHowToSolveIt.pdf.

Pratiwi, Diah Eka, and Mawardi Mawardi. "Penerapan Model Pembelajaran Inquiry dan Discovery Learning Ditinjau dari Keterampilan Berpikir Kritis Pada Mata Pelajaran Matematika Di Sekolah Dasar.” Jurnal Basicedu 4, no. 2 (March 4, 2020): 288-94. https://doi.org/10.31004/basicedu.v4i2.345.

Pratiwi, I. M., S. P. D. Rachman, and V. A. N. Ariawan. "Students' Mathematical Understanding Reviewed by Gender through Discourse Learning Assisted by Mathematical Bet Line Strategy.” Journal of Physics: Conference Series 1157 (February 2019): 042103. https://doi.org/10.1088/1742-6596/1157/4/042103.

Prayitno, Lydia Lia, Ida Sulistyawatii, and Imas Srinana Wardani. "Profil Kemampuan Berpikir Kritis Siswa SD Di Kecamatan Bulak.” Jurnal Pendidikan Dasar Nusantara $1, \quad$ no. 2 (January 13, 2016 ). https://ojs.unpkediri.ac.id/index.php/pgsd/article/view/216.

Sani, Ridwan Abdulllah. Pembelajaran Berbasis HOTS (Higher Order Thinking Skills). Tangerang: Tira Smart, 2019.

Suandito, Billy. "Bukti Informal Dalam Pembelajaran Matematika." Al-Jabar : Jurnal Pendidikan Matematika 8, no. 1 (June 19, 2017): 13-24. https://doi.org/10.24042/ajpm.v8i1.1160.

Suci, Dwi Wulan, Firman Firman, and Neviyarni Neviyarni. "Peningkatan Keterampilan Berpikir Kritis Siswa Melalui Pendekatan Realistik Di Sekolah Dasar.” Jurnal Basicedu 3, no. 4 (November 16, 2019): 2042-49. https://doi.org/10.31004/basicedu.v3i4.229.

Sukmadinata, Nana Syaodih. Metode Penelitian Pendidikan. Bandung: Remaja Rosdakarya, 2015. 
Sumarwati -. "Soal Cerita Dengan Bahasa Komunikatif Untuk Meningkatkan Kualitas Pembelajaran Matematika Sekolah Dasar." Jurnal Ilmu Pendidikan 19, no. 1 (2013). https://doi.org/10.17977/jip.v19i1.3752.

Susanto, Ahmad. Teori Belajar Dan Pembelajaran Di Sekolah Dasar. Jakarta: Kencana Prenada Media Group, 2013.

Utami, Rini. "Model Pembelajaran Berbasis Masalah Dengan Langkah Penyelesaian Berdasarkan Polya Dan Krulik-Rudnick Ditinjau Dari Kreativitas Siswa.” Delta: Jurnal Ilmiah Pendidikan Matematika 1, no. 1 (August 14, 2017): 82-98. https://doi.org/10.31941/delta.v1i1.464.

Zetriuslita, Zetriuslita, Rezi Ariawan, and Hayatun Nufus. "Analisis Kemampuan Berpikir Kritis Matematis Mahasiswa Dalam Menyelesaikan Soal Uraian Kalkulus Integral Berdasarkan Level Kemampuan Mahasiswa.” Infinity Journal 5, no. 1 (February 1, 2016): 56-66. https://doi.org/10.22460/infinity.v5i1.p56-66. 
Mathematical Critical Thinking Skills...

14| Al-Bidayah, Volume 12, Number 1, June 2020 